\title{
Characteristics of strike-slip inversion structures of the Karatau fault and their petroleum geological significances in the South Turgay Basin, Kazakhstan
}

\author{
Yin Wei ${ }^{1,2 *}$, Fan Zifei ${ }^{2}$, Zheng Junzhang ${ }^{2}$, Yin Jiquan², Zhang Mingjun ${ }^{2}$, \\ Sheng Xiaofeng ${ }^{2}$, Guo Jianjun ${ }^{2}$, Li Qiyan ${ }^{2}$ and Lin yaping ${ }^{2}$ \\ ${ }^{1}$ China University of Geosciences, Beijing 100083, China \\ ${ }^{2}$ Research Institute of Petroleum Exploration \& Development, PetroChina, Beijing 100083, China \\ (C) China University of Petroleum (Beijing) and Springer-Verlag Berlin Heidelberg 2012
}

\begin{abstract}
The Karatau fault is one of the important strike-slip faults in central Asia, and the South Turgay Basin is located towards its northern end. Detailed seismic interpretation indicated that the strikeslip tectonism of the Karatau fault weakened gradually from west to east in the South Turgay Basin. Typical flower structures developed on the section, and strike-slip faults showed an echelon pattern on planar view. The Karatau strike-slip fault affected the South Turgay Basin in two periods: (1) The South Turgay strike-slip pull-apart rift basin formed as a result of regional extensive stress in the Early-Middle Jurassic, characterized by the juxtaposition of horsts and grabens. The formation of horsts provided favorable reservoir spaces for later hydrocarbon accumulation, and different filling stages of grabens controlled different reservoir-forming factors in grabens. (2) Two stages of tectonic inversion occurred in the Late Jurassic and Late Cretaceous and played a crucial role in the final shape of the structure in the South Turgay Basin. The oil and gas migrated to form reservoirs and mainly concentrated in the horsts, graben slopes and in both sides of the strike-slip fault zone. In the case of the degree of accumulation of petroleum, the factor explaining why horsts are better than grabens is the strike-slip pull-apart of the South Turgay Basin, and the structure inversion of the South Turgay Basin explains why the west graben is better than the east one. Overall, the Karatau strike-slip fault played a very important role in the formation of the South Turgay Basin and its hydrocarbon accumulations.
\end{abstract}

Key words: South Turgay Basin, Karatau fault, tectonic style, strike-slip inversion, petroleum geological significance

\section{Introduction}

Strike-slip tectonics can form complex structural systems, to which more and more traps found in petroleum exploration are related. These include the San Andres fault belt (Fuis et al, 2001; Shaw and Shearer, 1999; Dolan et al, 2003; Oskin et al, 2000), the New Zealand Alpine fault belt (King, 2000; Barnes et al, 2005), Chinese Altun (Zhang et al, 2006; Zheng et al, 2003) and the Tanlu fault belts (Deng et al, 2008). The South Turgay Basin is one of the important petroliferous basins in central Asia. The Karatau fault, a strike-slip active fault, which passes across central Asia, plays a very important role in the formation of the South Turgay Basin and its hydrocarbon accumulation. The formation of the Karatau fault has been analyzed (He et al, 1995; Luo et al, 2004; Zhou et al, 2005; Allen et al, 2001; Alexeiev et al, 2009) from the regional geology, however, few studies have been done on

*Corresponding author. email: yinwei600@petrochina.com.cn Received November 13, 2011 how the Karatau strike-slip fault affected the formation and evolution of the South Turgay Basin and its hydrocarbon accumulation. In this study, on the basis of thorough investigation and detailed seismic data interpretation, the tectonic styles and distribution features of strike-slip faults were identified. Meanwhile, we quantitatively analyzed the extension rate and inversion strength. All of the work has revealed the controlling effects of strike-slip faults on hydrocarbon accumulation.

\section{Regional geological conditions}

The South Turgay Basin is located in central Kazakhstan, trending northwest-southeast and has an area of about $8 \times 10^{4} \mathrm{~km}^{2}$. It is one of the important petroliferous basins in Kazakhstan. To the north of the South Turgay Basin is the North Turgay Basin, to the west is the Ural Suture Belt, and to the east is the Ulutau Uplift. The South Turgay Basin is separated by a narrow uplift from the Chu-Sarysu Basin to the southeast. Three secondary tectonic units can be distinguished, and the sedimentary center as well as the 
discovered petroleum resources are mainly located in the southern sag. The South Turgay Basin mentioned below is referred to as the southern sag (backslash area). The Karatau fault is one of the important strike-slip faults in central Asia, joined by the large fault belt of the Ural orogenic belt to the northwest, through the northeast Fergana Basin, then entering the Kashi Depression in the west Tarim Basin to the southeast
(Buslov, 2011; Moseley and Tsimmer, 2000). The South Turgay Basin is located on the northmost part of the Karatau strike-slip fault, characterized by the juxtaposition of horsts and grabens, in sequence of the Aryskum Graben, Aksay Horst, Akshabulak Graben, Ashisay Horst, Sarylan Graben, Tabakbulak Horst, and Bozingen Graben from west to east (Figs. 1 and 2).

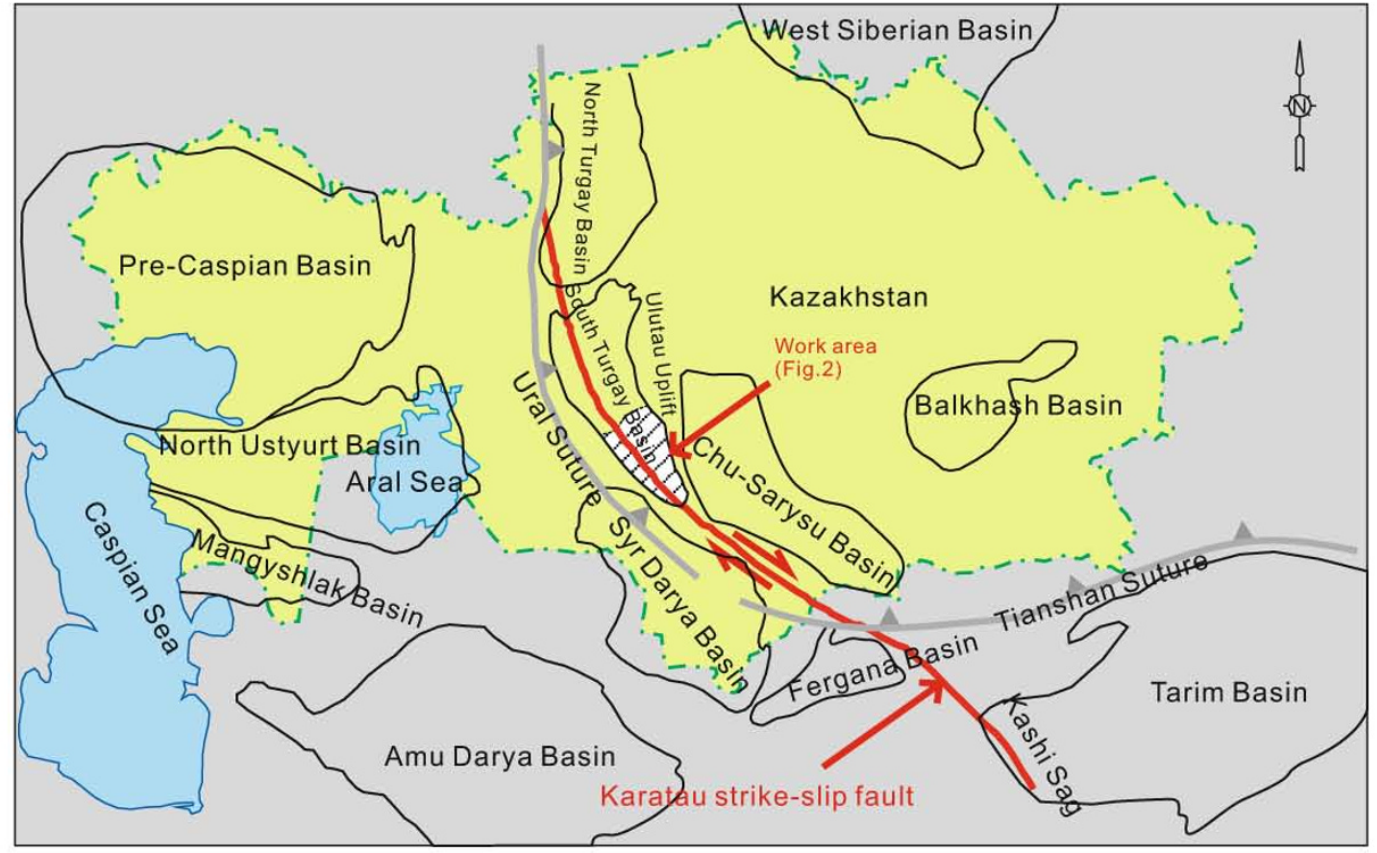

Fig. 1 Location of South Turgay Basin

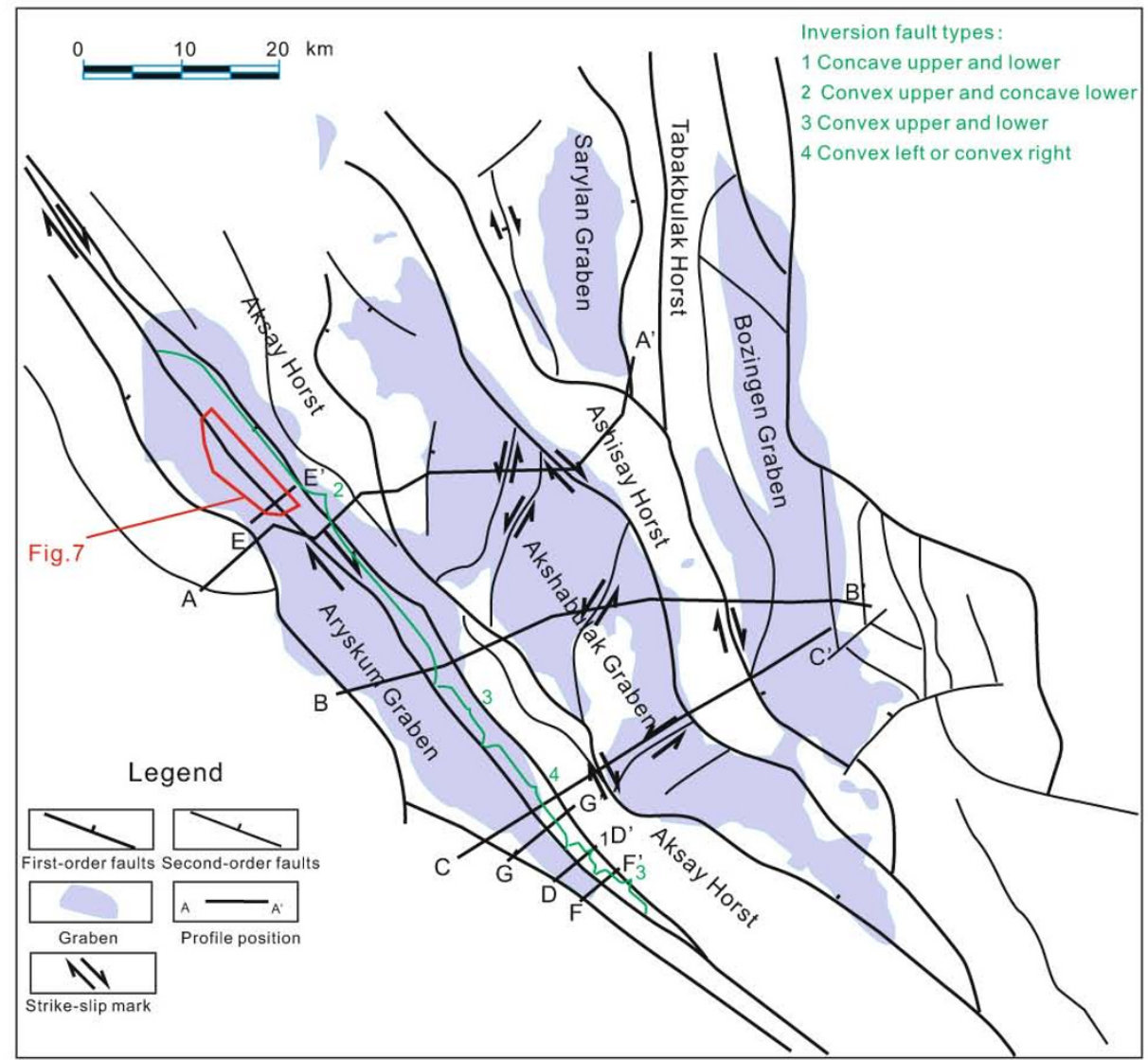

Fig. 2 Tectonic framework and distribution of faults of the South Turgay Basin 
Jurassic and Cretaceous strata are the main target layers in the South Turgay Basin, and the major source rock is a large set of thick mudstones deposited in the Middle-Lower Jurassic deep lake-semi-deep lake facies. The Upper Jurassic and Cretaceous sandstone and siltstone deposited in delta and fluvial facies are the major reservoirs, where most of the petroleum discovered so far is distributed. The thick Lower Cretaceous mudstone in $\mathrm{K}_{1} \mathrm{nc}_{1}$ Formation is the regional cap rock. As shown in Fig. 3, several sets of reservoir-seal assemblage are developed in vertical section in the South Turgay Basin, so the basin has large exploration potential.

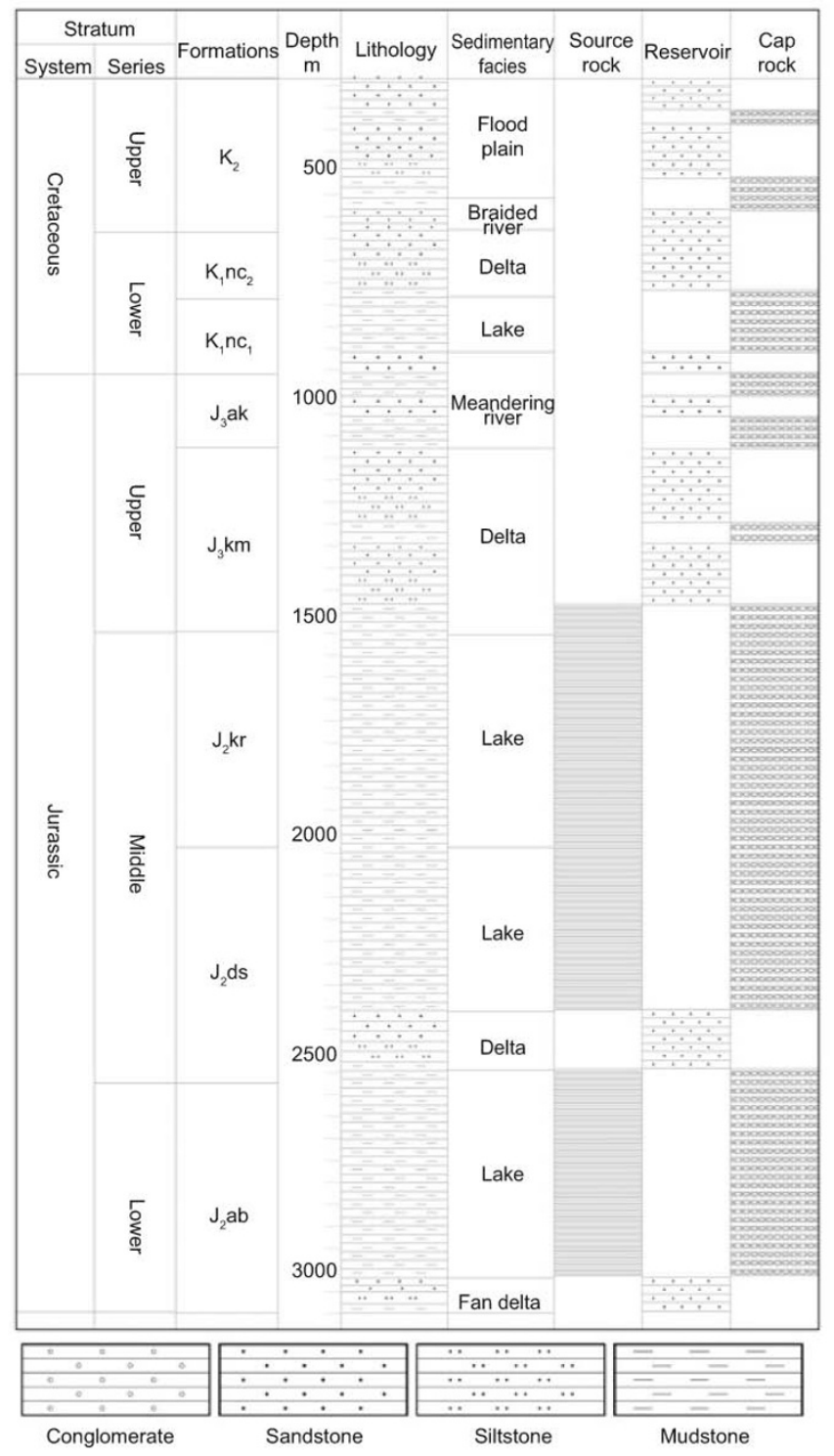

Fig. 3 Comprehensive stratigraphic column of the South Turgay Basin

\section{Tectonic styles of the Karatau strike-slip fault}

The strike-slip fault, generated under a particular stress background, characterized by both sides of the fault blocks moving along the strike with a sliding displacement, always has a series of special geometric characteristics (Xia et al, 2007). These geometric characteristics are important signs used to identify whether a strike-slip fault exists or not.

\subsection{Regional distribution characteristics of the Karatau strike-slip fault}

The Karatau strike-slip fault can be divided into two groups on planar view. One group is distributed in the shape of broom, striking northwest-southeast, with dextral strikeslip. This large scale group of faults controls the major tectonic and sedimentary framework. The other is a group of northeast-southwest sinistral strike-slip faults, which controls some small scale slopes or tectonic zones (Fig. 2). Therefore, the Karatau strike-slip fault is a fault system consisting of two groups of faults with different scales.

There are significant differences in the strike-slip tectonism of different grabens in the South Turgay Basin. From the profile $\mathrm{AA}^{\prime}, \mathrm{BB}^{\prime}$ and $\mathrm{CC}^{\prime}$ in Fig. 4, we can see that strike-slip tectonism occurred intensely in the Aryskum Graben, causing obvious and typical strike-slip tectonic movement. Steep fault planes were developed in the main faults, which can extend into the basement, and also reach the surface. As well, flower structures developed in shallow layers. The fault scale became smaller in the Akshabulak Graben, and most of the faults ended in the Upper Jurassic. The Sharalan and Bozengen grabens showed their strikeslip feature only in the western edge controlled faults, and then trended into normal faults in the east. From these characteristics, we can conclude that the Karatau strikeslip tectonism weakened gradually from west to east (Fig. 4). Therefore we will mainly discuss the profile and plane distribution characteristics of the Karatau strike-slip fault in the Aryskum Graben.

\subsection{Profile characteristics of the Karatau strike-slip fault}

Typical flower structures were well developed in the Karatau strike-slip fault. During the process of their formation, the flower structures always underwent compression and torsion in different degrees and further formed strike-slip inversion structures. The inversion structure of South Turgay is not a simple one, and at the same time, it has strike-slip features. Therefore, the inversion characteristics (positive or negative) are not obvious after large scale horizontal displacement of stratum. According to the compression and torsion strength and the inversion degree of strata, the profile shapes of the Aryskum Graben in the South Turgay Basin can be qualitatively divided into four types: concave upper and lower, convex upper and concave lower, convex upper and lower, and convex left or convex right (Fig. 5).

The concave upper and lower type (B in Fig. 5) has a slight strike-slip compression, with slight inversion of the strata, which can be seen in some south areas of the Aryskum Graben (DD'). The convex upper and concave lower type (C in Fig. 5) has experienced moderate compression, where the degree of inversion is large in the upper strata, but small in the lower strata. This type is commonly distributed in most northern areas of Aryskum Graben (EE'). Strong strike-slip compression occurred in the convex upper and lower type (D in Fig. 5), where the dips of upper and lower strata all changed. This case can be mainly seen in stress centralized 

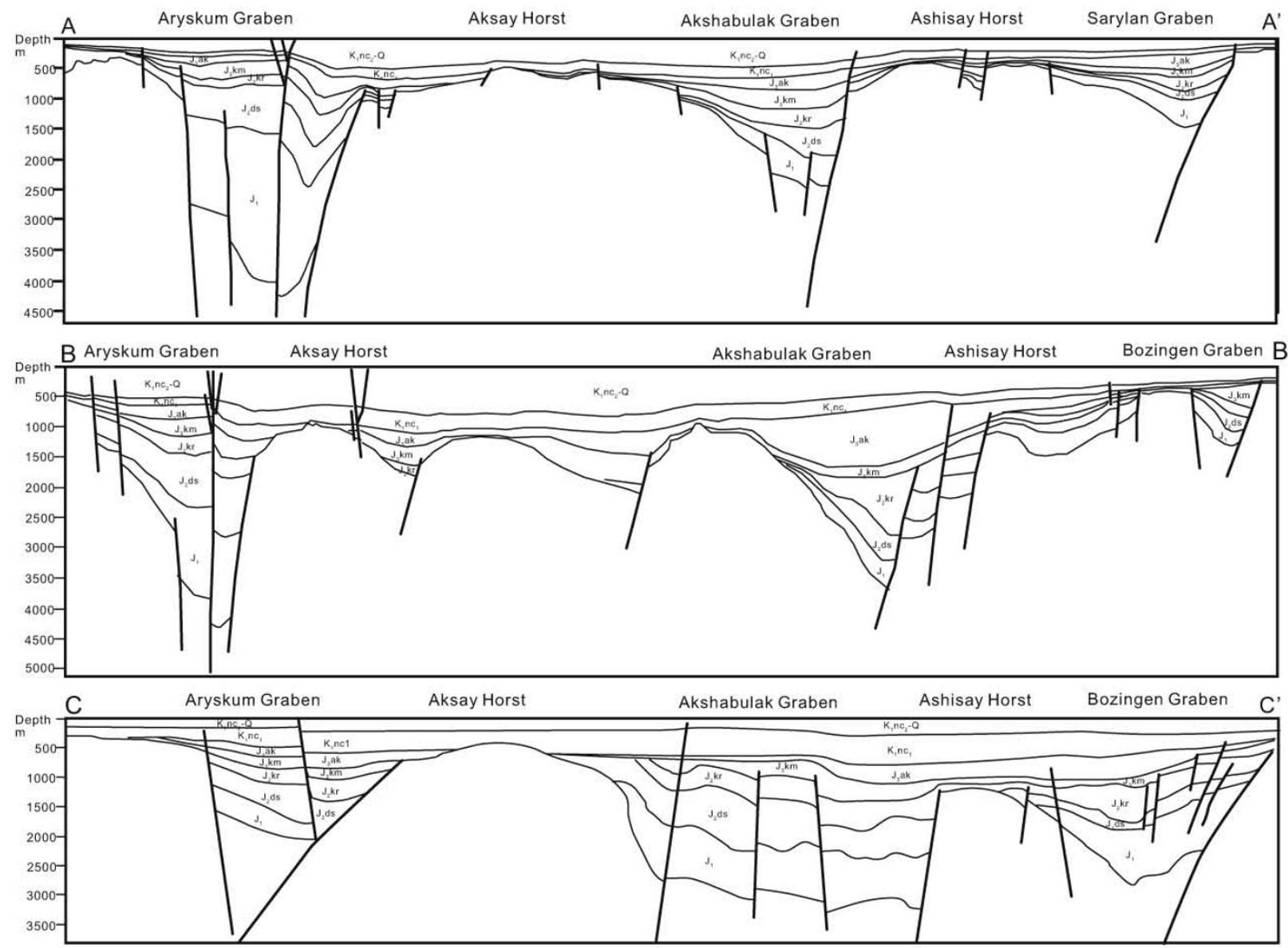

Fig. 4 Profile features of the Karatau strike-slip fault of the South Turgay Basin

release area of the southern part of the basin (FF'). The convex left (E in Fig. 5) or convex right type ( $\mathrm{F}$ in Fig. 5) is produced by the different compression on the two sides of the strike-slip fault. In the Aryskum Graben, the concave left and convex right type was mainly developed, where the right side suffered intense compression, resulting in obvious inversion, whereas the compression was much weaker in the left side (GG') (Figs. 2 and 6).

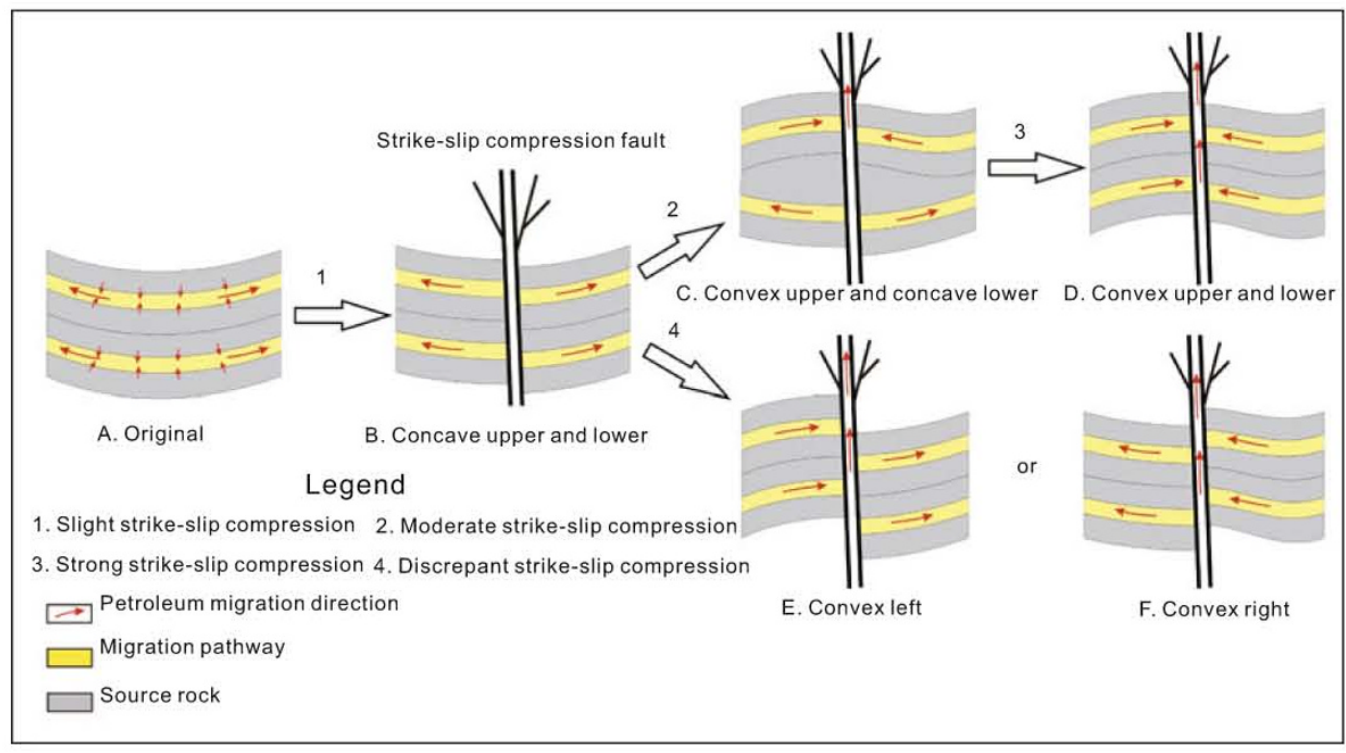

Fig. 5 Types and accumulation patterns of inversion tectonics in Aryskum Graben of the South Turgay Basin 


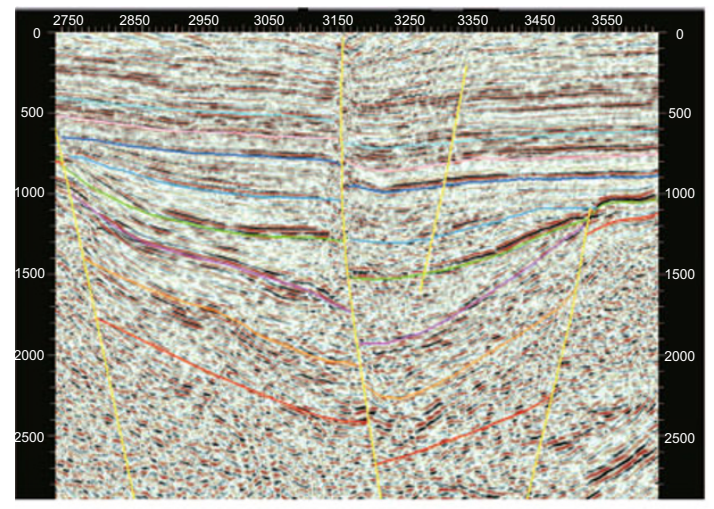

Concave upper and lower (DD')

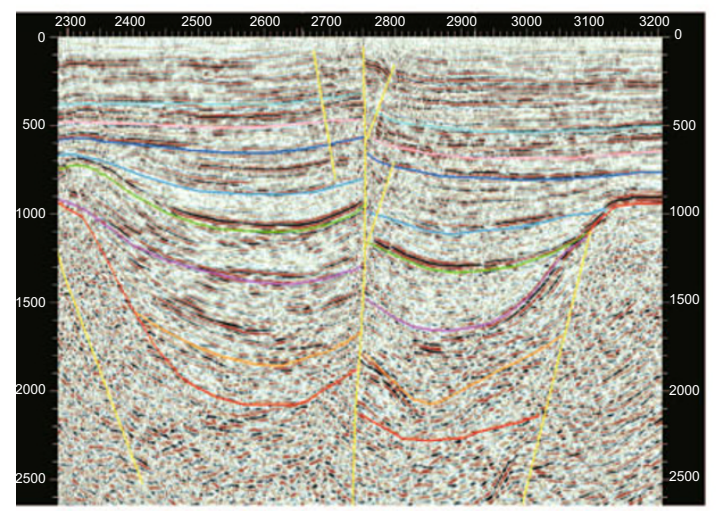

Convex upper and lower (FF')

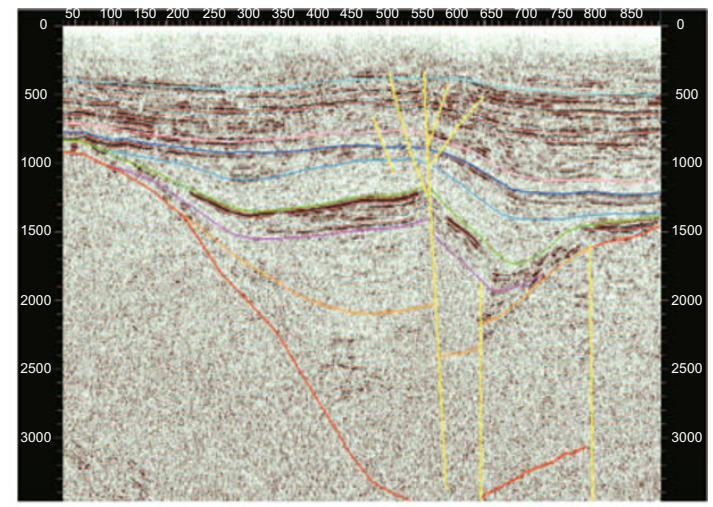

Convex upper and concave lower (EE')

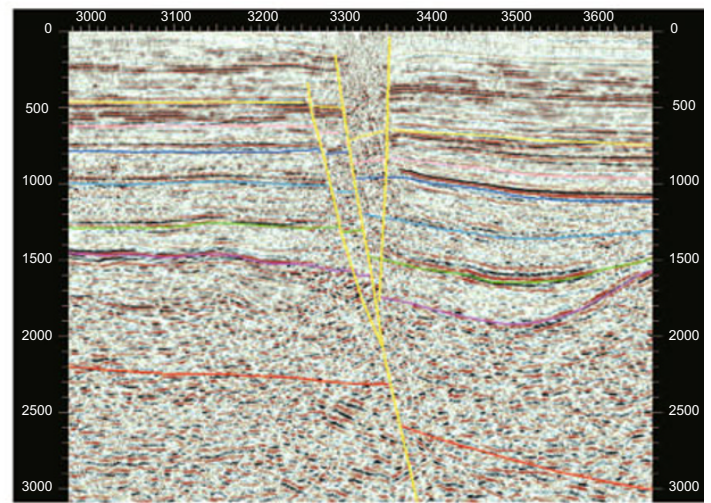

Concave left and convex right (GG')

Fig. 6 Profile characteristics of strike-slip faults in the Aryskum Graben of the South Turgay Basin

\subsection{Plane distribution characteristics of the Karatau strike-slip fault}

An echelon pattern on planar view is a typical feature of strike-slip faults. The Akshabulak Graben developed a total of four large-scale adjusting faults in an echelon pattern, which controlled the secondary tectonic units within the graben (Fig. 3). In middle Aryskum Graben, on both sides of the strike-slip fault, a series of smaller echelon pattern faults developed, which controlled the local structural traps. These trap-level adjusting faults strike mainly NNE and locally NNW, and intersect with the primary fault striking northwestsoutheast. These echelon pattern faults are $0.7-3.8 \mathrm{~km}$ long, and the vertical distance is $0.2-2 \mathrm{~km}$. In the north of the threedimensional region, the fault tectonic units are distributed in a diamond shape in the plane, and these diamond-shaped tectonic units are another typical feature of strike-slip faults on planar view (Fig. 7). The echelon pattern faults are obvious in the profile, but have little fault displacement (Fig. 8).

\section{Formation of the South Turgay Basin under the control of the Karatau strike-slip fault}

The Karatau strike-slip fault belt began to develop in the Early Proterozoic, when it was sinistral, with little slip. At the end of the Late Paleozoic, with the South Tianshan Ocean closed, large-scale dextral strike-slip movement occurred

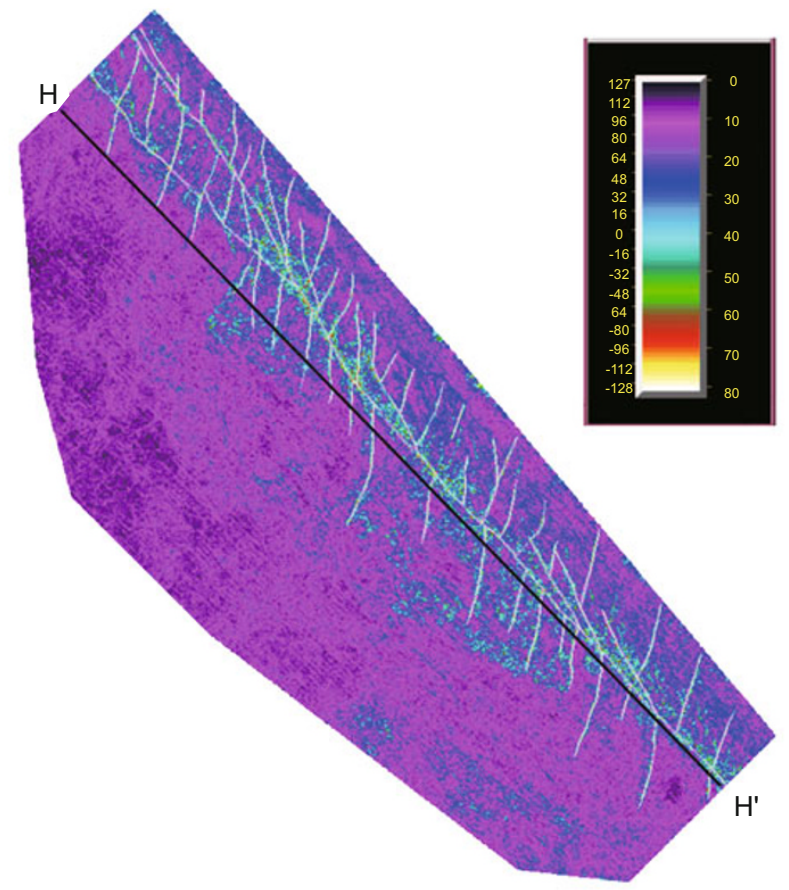

Fig. 7 Planar distribution of echelon pattern faults in a three-dimensional region in the Aryskum Graben (coherent horizon slice along $\mathrm{J}_{3}$ ak Formation $20 \mathrm{~ms}$ upper and lower)

in the Karatau strike-slip fault belt (Burtman, 1980). The Karatau strike-slip faults affected the South Turgay Basin in two periods: Early-Middle Jurassic and Late Jurassic-Late 


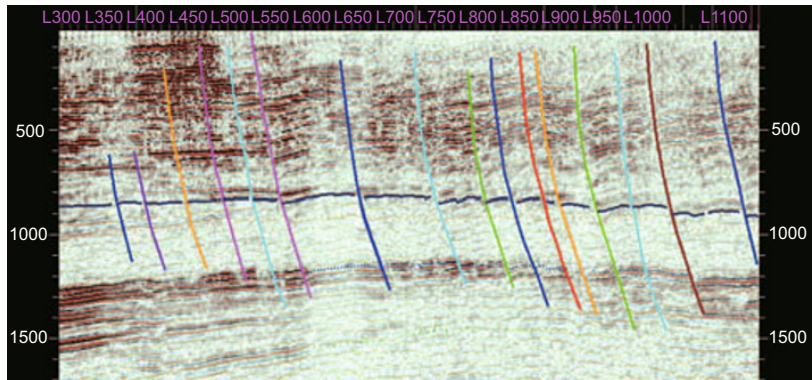

Fig. 8 Seismic survey line Trace 1430 (HH') in a three-dimensional region in South Turgay Basin

Cretaceous. During the former period, strike-slip pull-apart rift basins formed, whereas during the latter period tectonic inversion occurred and the final distribution of the traps was set.

\subsection{Formation of the strike-slip pull-apart rift basins under the control of the Karatau strike-slip fault in the Early-Middle Jurassic}

In the Early-Middle Jurassic, with the close of the South Tianshan Ocean, the north areas were in an extensional state of different degrees. The Karatau strike-slip fault was of tension-torsional type at that time. A series of strike-slip pullapart basins including the South Turgay Basin formed along the Karatau strike-slip fault (Luo et al, 2004; Zhou et al, 2005). Based on the analysis of the tectonic characteristics of the regional profiles of $\mathrm{AA}^{\prime}, \mathrm{BB}^{\prime}$ and $\mathrm{CC}^{\prime}$, the extension rate and the extension coefficient of the basin were calculated. As shown in Fig. 9 to Fig. 11, the extension rate in the Early Jurassic, Middle Jurassic, and Late Jurassic can reach 0.068, 0.048 , and 0.017 , respectively. Meanwhile, the extension coefficient in the Early Jurassic, Middle Jurassic, and Late Jurassic reaches 1.07, 1.05, and 1.01, respectively. Therefore, the extension of the South Turgay Basin was the strongest in the Early Jurassic, the next is Middle Jurassic, and the weakest is the Late Jurassic. That was to say the extension gradually weakened from the Early Jurassic to Late Jurassic. On planar view, profile $\mathrm{AA}^{\prime}$ and $\mathrm{CC}^{\prime}$, located on the southern and northern sides respectively, both have large extension rate and extension coefficient, whereas the values are much smaller in profile $\mathrm{BB}^{\prime}$ in the central basin. Therefore, the extension of the basin was strong in the north and south, but weak in the middle of the basin (Figs. 9 to 11).
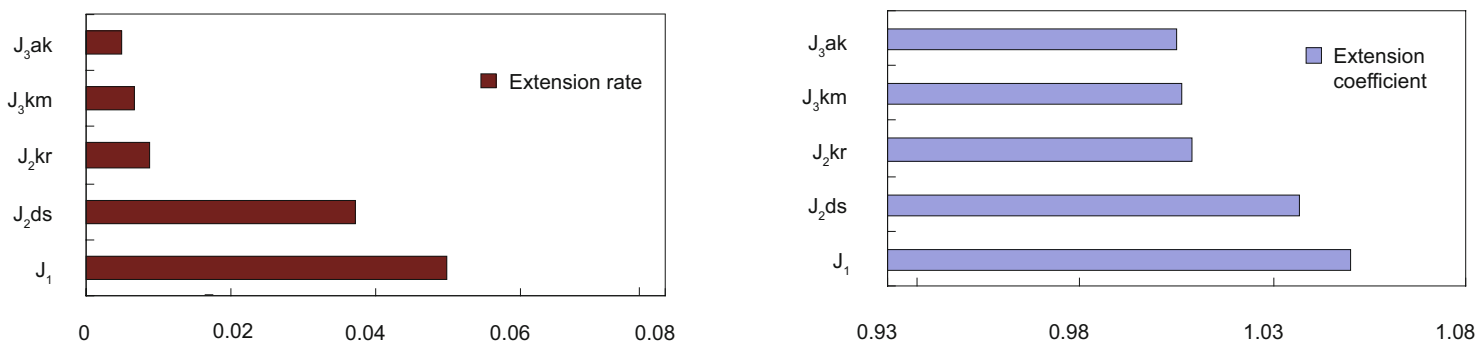

Fig. 9 Extension rate and extension coefficient of profile AA'
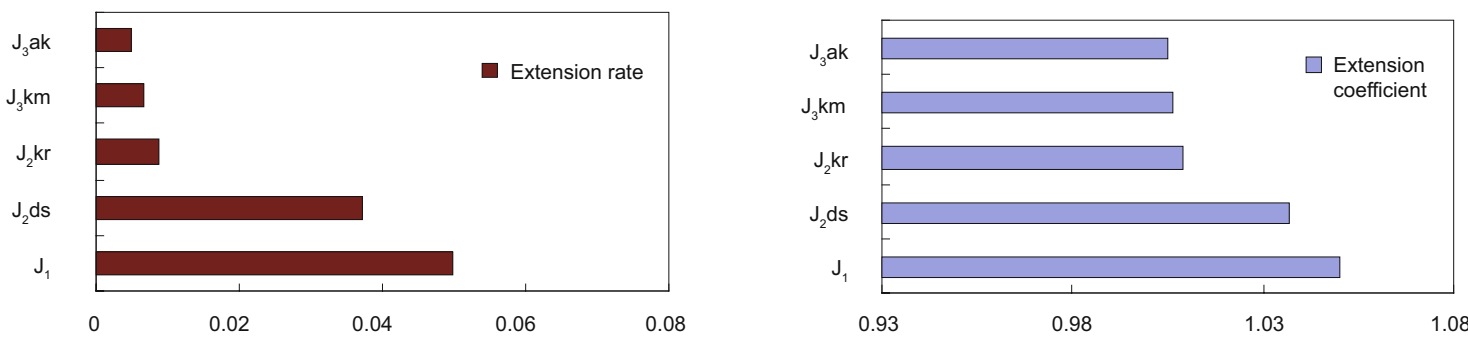

Fig. 10 Extension rate and extension coefficient of profile BB'.
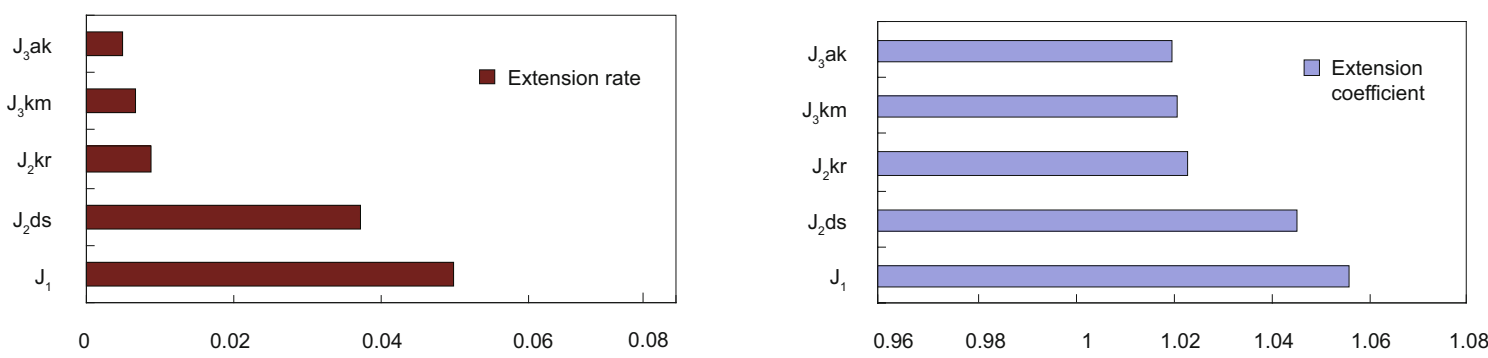

Fig. 11 Extension rate and extension coefficient of profile CC' 


\subsection{Two stages of tectonic inversion under the control of the Karatau strike-slip fault in the Late Jurassic and Late Cretaceous}

With the influence of the Yanshan movement, the Karatau strike-slip fault experienced two stages of positive NW-SE inversion in the Late Jurassic and Late Cretaceous (Alexeiev et al, 2009; Buslov, 2011), which can be further divided into two types: fault-type and fold-type. The fault-type inversion structures were widely distributed in the Aryskum Graben, southern and northeastern areas of the basin, while the fold-type inversion structures were distributed only in the southeastern basin and part areas of the northern fault depressions.

Williams et al (1989) proposed a method of calculating the degree of inversion of inversion faults, that is the inversion ratio $\left(R_{\mathrm{i}}\right), R_{\mathrm{i}}=d c / d h$, where $d c$ is the formation thickness above the zero point of the hanging wall, $d h$ is the total formation thickness of the hanging wall (Williams et al, 1989; Liu et al, 2009; Wang, 2010) (Fig. 12). In view of the fault-type inversion structures, choosing the balance point of tension and compression as the zero point, $d c$ is the distance along the fault plane from top boundary of the inversion extension sequence to the zero point, and $d h$ is the whole formation length along the fault plane. As to the fold-type inversion structures, we choose the line connecting the extreme values of tension and compression as the axes. The inversion process is taken as the formation slipping up along the axes (Fig. 13) and then the inversion ratio of different inversion structures in the South Turgay Basin is calculated.

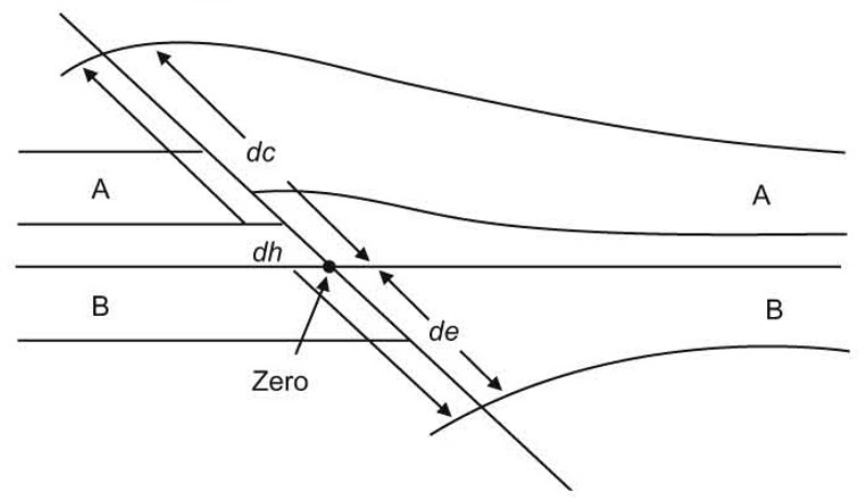

Fig. 12 Sketch map showing parameters for the inversion ratio $\left(R_{\mathrm{i}}\right)$ calculation (Williams et al, 1989)
The result shows that large-scale inversion has occurred in the Aryskum Graben, especially in the convex upper and lower type and convex upper and concave lower type tectonic styles, whose inversion strength is the largest. Next is the concave left and convex right type, and the least is the concave upper and lower type. The fold-type inversion structures play a dominant role in the middle of the Aryskum Graben, with a low degree of inversion along the strike-slip faults. The inversion strength in the southeastern part of the basin is also large, mostly beyond 0.7 in $R_{\mathrm{i}}$. Compared with above two areas, the northeastern section has lower inversion strength, with the $R_{\mathrm{i}}$ of only 0.18 in local areas (Fig. 14).

\section{Petroleum geology significance of the Karatau strike-slip fault}

The early pull-apart of the strike-slip fault controlled the tectonic framework and sedimentary system, which further controlled the distribution of source rocks, reservoirs, and cap rocks. The later tectonic inversion controlled the formation of traps and petroleum migration and accumulation (Xu et al, 2010; Xu et al, 2011a; 2011b).

\subsection{Tectonic framework and sedimentary system in the strike-slip pull-apart basin}

The strike-slip pull-apart of the Karatau strike-slip fault directly controlled the formation, growth and tectonic styles of the South Turgay Basin, forming the geologic structure characterized by the juxtaposition of horsts and grabens. Good structural shapes developed in the horst area, together with the later weathering and denudation, reservoirs with favorable properties were formed, thus provided good reservoir space for later petroleum accumulation. The sediment fill of the grabens can be divided into three stages: (1) In faulted period of the Early and Middle Jurassic, the sedimentation was mainly concentrated in the center of the grabens, with mudstones of deep lake-semi-deep lake facies, and fan delta sandstones developed in slope areas. Therefore, the distribution of source rocks and the lithologicstratigraphic traps were controlled in this period. (2) In the fault-depression transform period of the Late Jurassic, the fault depression shrank and depressions formed gradually, so the sedimentary area expanded significantly. The dominant types of sedimentary facies were delta and fluvial facies. (3)
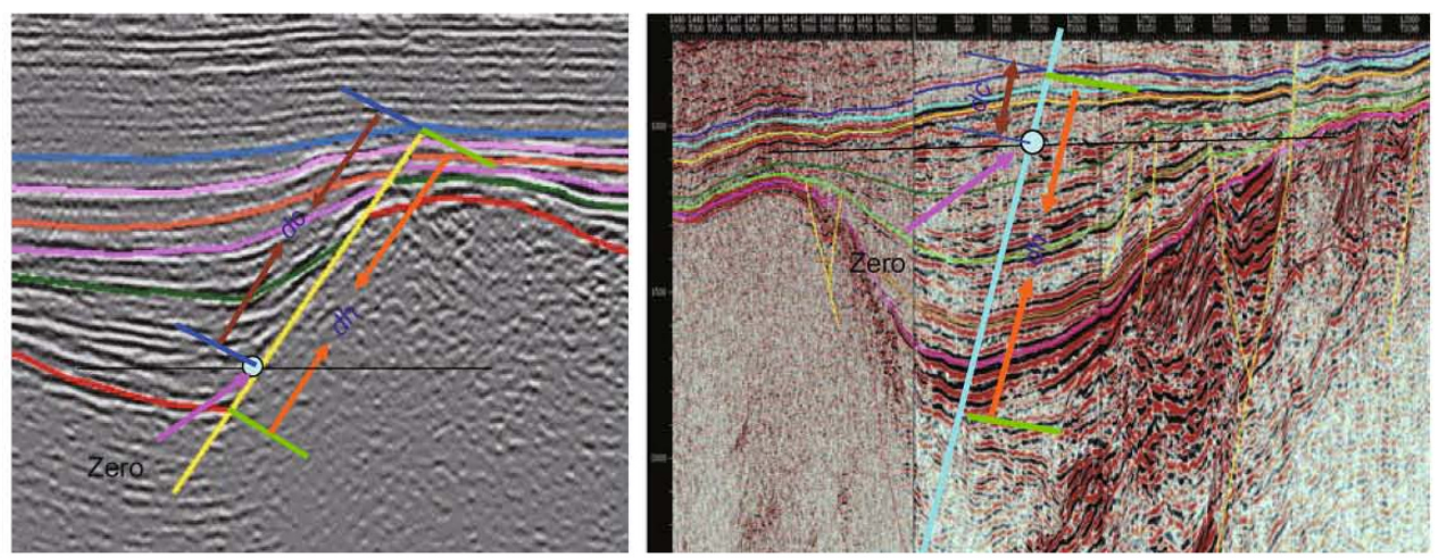

Fig. 13 Schematic diagram showing $R_{\mathrm{i}}$ calculated in fault-type (left) and fold-type (right) inversion 


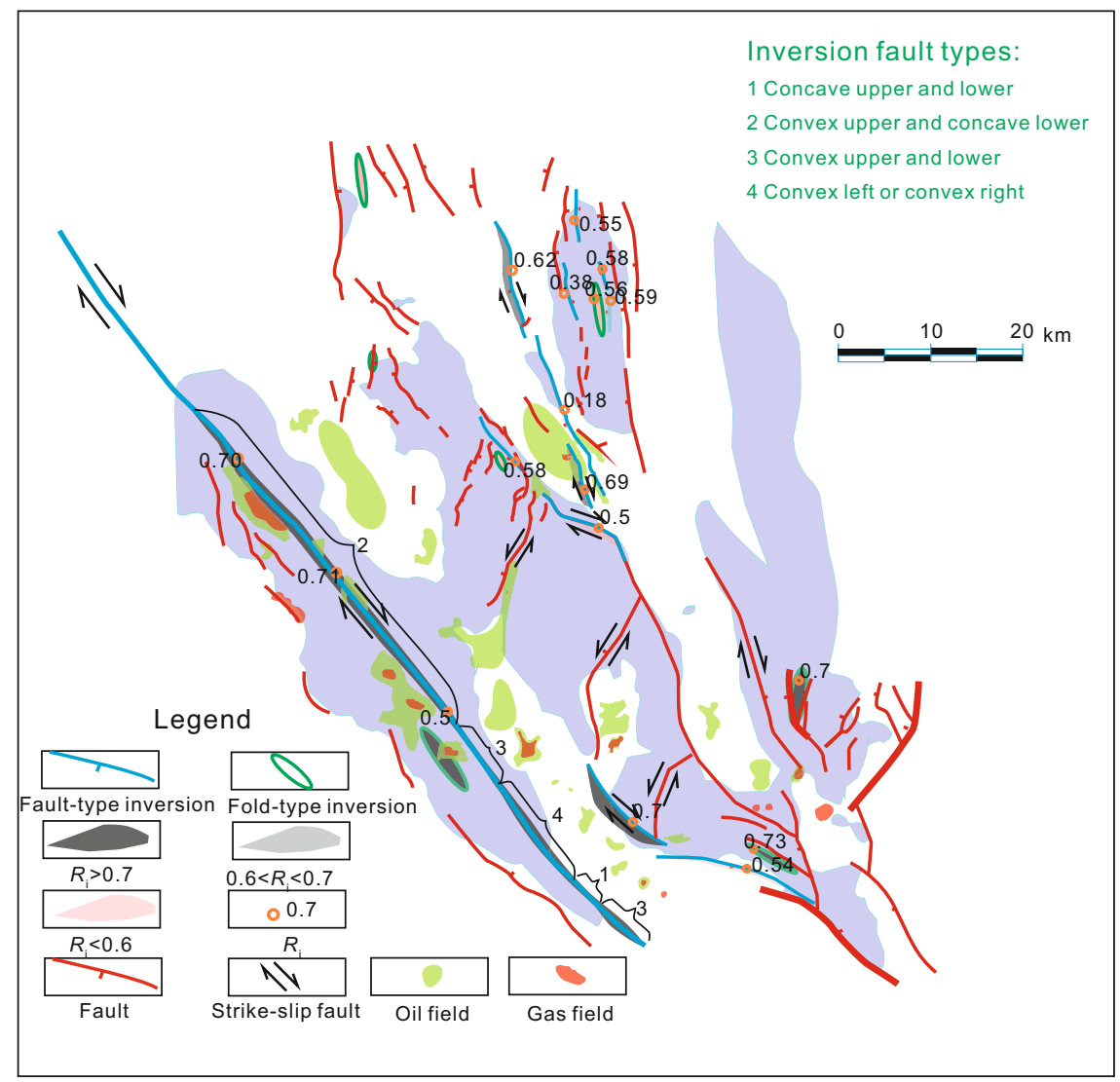

Fig. 14 Types, strength and petroleum accumulation of inversion tectonics in the South Turgay Basin

In the Cretaceous depression epoch, sediments covered the whole area, mainly composed of fluvial, delta, and floodplain deposits. The distribution of reservoirs and regional caps were determined in the Late Jurassic and Cretaceous. From the above analysis, we find that different reservoir-forming factors were controlled in different stages (Fig. 15).

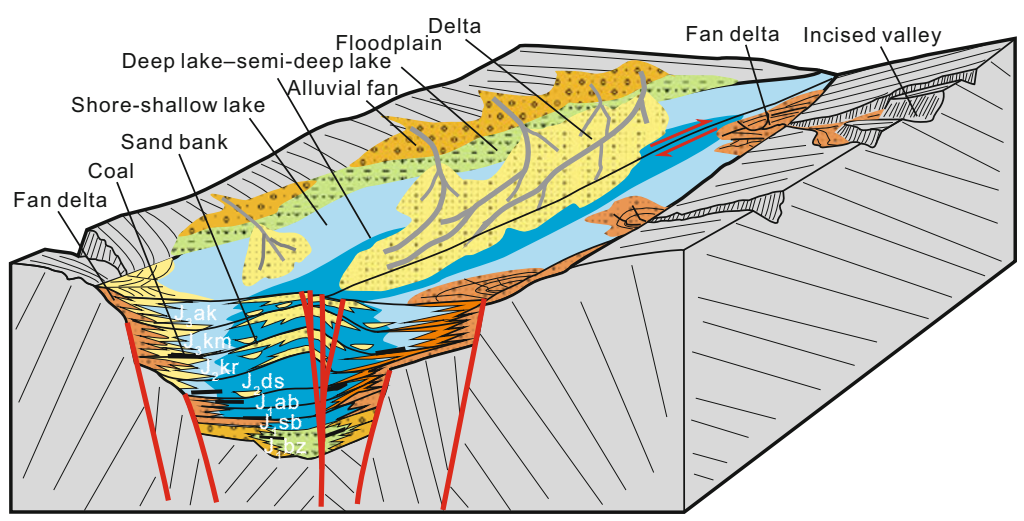

Fig. 15 Model graph of tectonic-sedimentary framework of the Aryskum Graben in the South Turgay Basin

\subsection{Hydrocarbon generation and expulsion amount and the accumulation patterns changed by tectonic inversion}

(1) Concave upper and lower type tectonic inversion had little influence on the hydrocarbon generation and expulsion amount, and the hydrocarbon accumulation patterns. The generated hydrocarbon mainly migrated from the central basin to the edge along lateral migration pathways, and accumulated in lithologic-stratigraphic traps at the basin margin.

(2) Under the influence of uplift, strata were lifted, temperature and pressure were decreased, so convex upper and concave lower type inhibited the hydrocarbon generation amount of upper source rocks, while the lower source rocks were basically not influenced. The upper generated hydrocarbon mainly migrated to strike-slip faults along lateral migration pathways, and then migrated upward until it accumulated in shallow traps. However, the lower 
hydrocarbon mainly migrated from the central graben to the edge, and accumulated in suitable traps.

(3) The convex upper and lower type resulted in a change of the dips of upper and lower hydrocarbon source beds, and the hydrocarbon generation amount of all the source rocks was inhibited. The generated hydrocarbon migrated toward the faults along lateral migration pathways, and then migrated up along the faults and accumulated in shallow traps.

(4) The concave left and convex right type inhibited the hydrocarbon generation amount of the right side source rocks, while the left side was basically not influenced. The right generated hydrocarbon migrated toward the faults along lateral migration pathways, and then migrated up along the faults and accumulated in shallow traps. However, the left hydrocarbon mainly migrated from the central graben to the edge, and accumulated in suitable traps (Fig. 5).

The major source rock of the South Turgay Basin is the Middle-Lower Jurassic dark mudstone. Therefore, the Middle-Lower Jurassic concave lower type is important in order to ensure abundant petroleum supply. In the case of hydrocarbon generation and expulsion amount, the types of convex upper and concave lower, concave upper and lower, and concave left have little influence on petroleum amount, and can guarantee oil and gas supply. However, the type of convex upper and lower has great influence on petroleum amount, and it is not favorable for source rocks to expel hydrocarbon. In the case of hydrocarbon traps, faulted noses, faulted anticlines and anticlines on both sides of the strikeslip fault are effective reservoir spaces, so the types of convex upper and lower, convex upper and concave lower, convex right, and convex left facilitate petroleum accumulation.

Comprehensive analysis suggests that the convex upper and concave lower type is the best one for petroleum generation and accumulation, next is convex upper and lower, and concave upper and lower and concave left or convex right are the worst. Fig. 14 revealed clearly that convex upper and concave lower and convex upper and lower accumulated a large amount of oil and gas in the north of the Aryskum Graben, but two other types had little oil and gas.

\subsection{Trap formation and hydrocarbon distribution controlled by tectonic inversion}

A structural framework of juxtaposed horsts and grabens was formed under the control of the strike-slip Karatau fault in the Early-Middle Jurassic, and the present status was formed under the control of inversion movements of the strike-slip fault in the Late Jurassic and Late Cretaceous. After experiencing intense compression during the inversion period, large area and high amplitude anticline traps were formed in the horst area, and faulted noses and faulted anticlines were formed on both sides of the strike-slip fault. These traps provided effective reservoir spaces for petroleum accumulation, and host the oil and gas discovered so far in the South Turgay Basin.

Two compressive events occurring in the Late Jurassic and Late Cretaceous formed a series of faulted anticlines and faulted nose structures along the strike-slip fault zone, which provided effective reservoir space for hydrocarbon accumulation (Fig. 16).

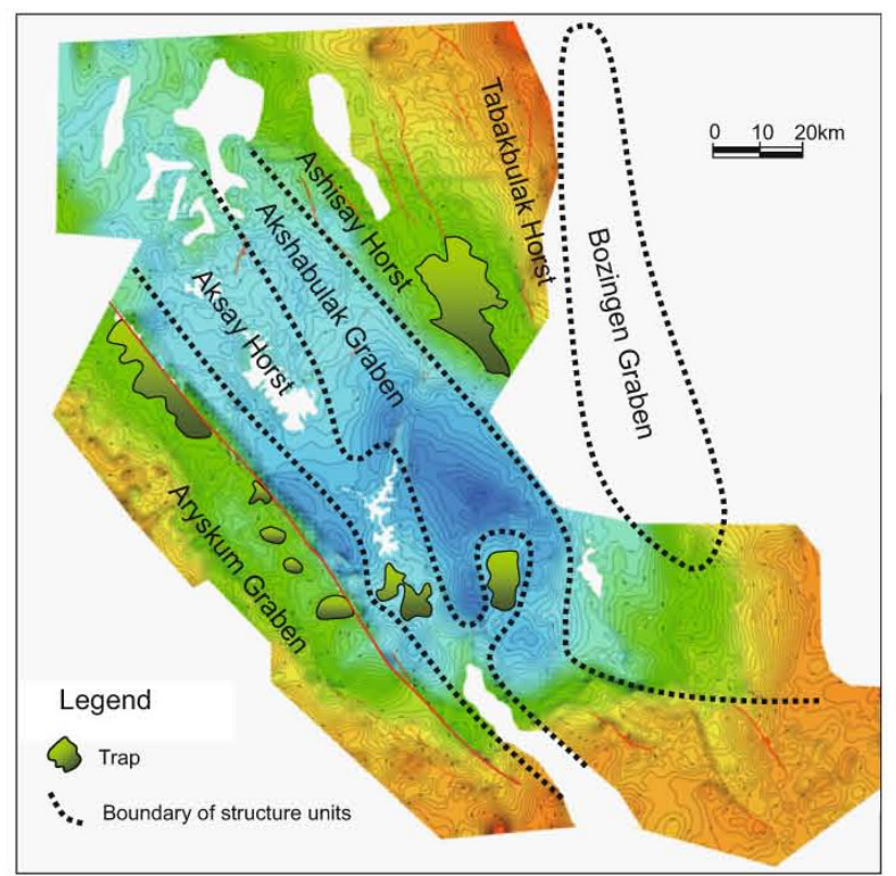

Fig. 16 Structure map of the top of $\mathrm{J}_{3} \mathrm{ak}$ in the South Turgay Basin

The Lower Jurassic source rocks of the South Turgay Basin started generating much hydrocarbon in the Late Jurassic, and the first hydrocarbon accumulation occurred in the tectonic inversion period also in the Late Jurassic. The Middle Jurassic source rocks started generating hydrocarbon in the Late Cretaceous, and the second hydrocarbon accumulation occurred in the tectonic inversion period in the Late Cretaceous, during which the previously formed reservoirs were adjusted and transformed. The dominant migration directions of oil and gas were: (1) lateral migration in the horst area and graben slopes, thus forming anticline pools in horsts and lithologic-stratigraphic reservoirs in graben slopes. (2) lateral-vertical migration on both sides of the strike-slip fault belt, forming fault nose (faulted block) reservoirs. Therefore, the two stages of tectonic inversion in Late Jurassic and Late Cretaceous facilitated secondary hydrocarbon migration and adjustment, then the reservoir shapes were finally set and the hydrocarbon distribution was stabilized (Fig. 14 and Fig. 17).

Horsts are better hosts for petroleum accumulation than grabens. Horsts were formed early in the strike-slip pull-apart period of the Early-Middle Jurassic, and reservoir properties were improved through long weathering and erosion. Moreover, anticlines on horsts are suitable for the long-term petroleum accumulation. Therefore the explanation of why horsts are better for petroleum accumulation than grabens is the strike-slip pull-apart of the South Turgay Basin.

Four grabens of the South Turgay Basin have great differences in the degree of accumulation of petroleum, and the west graben is better than the east one. This is caused by the difference in the degree of structure inversion in the South Turgay Basin. With the highest inversion degree, the Aryskum Graben accumulated the maximum petroleum. From west to east, the inversion degree reduced, and thus the petroleum accumulation reduced. Therefore, the explanation of why the west graben is better than the east one is the structure inversion of the South Turgay Basin (Fig. 14 and Fig. 17). 


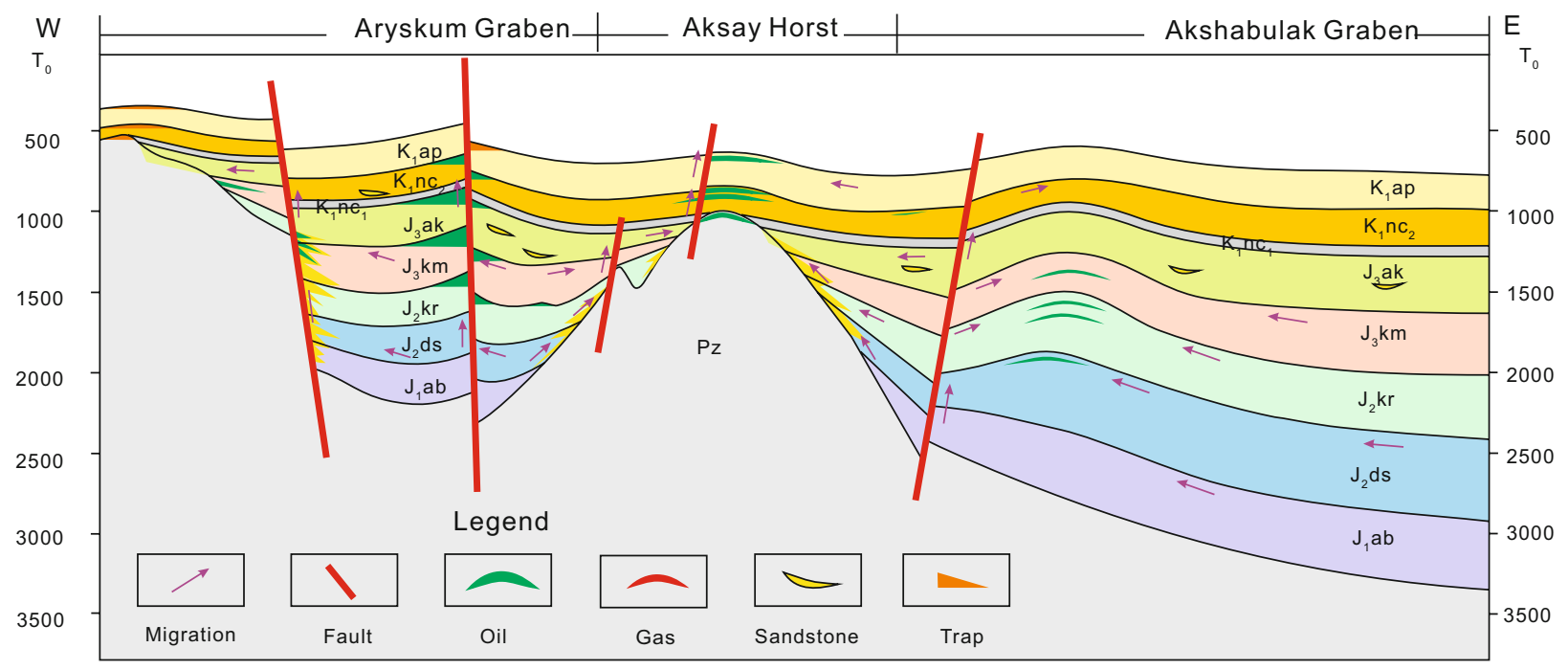

Fig. 17 Diagram of petroleum migration in the South Turgay Basin

\section{Conclusions}

1) The strike-slip tectonism of the Karatau fault in the South Turgay Basin weakened gradually from west to east. Typical flower structures are developed on the section, and strike-slip faults show an echelon pattern on planar view.

2) In the Early-Middle Jurassic, the South Turgay strikeslip pull-apart basin formed under the control of the Karatau strike-slip fault. The extension gradually weakened from the Early Jurassic to Late Jurassic, and the extension of the basin was strong in the north and south, but weak in the middle on planar view. Two stages of tectonic inversion occured in the South Turgay Basin, the Late Jurassic and Late Cretaceous, and the Aryskum Graben in the western and southern basin underwent strong inversion.

3) A geologic structure characterized by the juxtaposition of horsts and grabens was formed under the action of the strike-slip pull-apart Karatau fault. The formation of the horsts provided favorable reservoir spaces for later hydrocarbon accumulation, while different filling stages controlled different reservoir-forming factors in grabens. The hydrocarbon generation and expulsion amount and the migration direction were changed by tectonic inversion, which also created the final form of the hydrocarbon-bearing traps.

4) Three types of hydrocarbon-bearing structure formed in the South Turgay Basin. Anticline traps formed in the horst area, lithologic-stratigraphic traps in the graben slope area, and fault nose or fault block traps on both sides of the strike slip fault zone. The strike-slip pull-apart of the South Turgay Basin explains why horsts are better for petroleum accumulation than grabens, and the structure inversion of the South Turgay Basin explains why the west graben is better than the east one.

\section{Acknowledgements}

This project was supported by the Major National Science and Technology Projects of China (No. 2008ZX05029-002), and CNPC Research Topics of China (No.07B60101).

\section{References}

Alexeiev D V, Cook H E, Buvtyshkin V M, et al. Structural evolution of the Ural-Tian Shan junction: a view from Karatau ridge, South Kazakhstan. Comptes Rendus Geoscience. 2009. 341(2): 287-297

Allen M B, Alsop G I and Zhemchuzhnikov V G. Dome and basin refolding and transpressive inversion along the Karatau Fault System, Southern Kazakhstan. Journal of the Geological Society. 2001. 158(1): 83-95

Barnes P M, Sutherland R and Delteil J. Strike-slip structure and sedimentary basins of the Southern Alpine Fault, Fiordland, New Zealand. Geological Society of America Bulletin. 2005. 117(3-4): 411-435

Burtman V S. Faults of Middle Asia. American Journal of Science. 1980. 28(7): 725-744

Buslov M M. Tectonics and geodynamics of the Central Asian Foldbelt: the role of Late Paleozoic large-amplitude strike-slip faults. Russian Geology and Geophysics. 2011. 52(1): 52-71

Deng J H, Zhou X H, Wei G, et al. Strike-slip faulting activities in the Tanlu fault zone and their relationship with hydrocarbon accumulation - an example from Jinxian area. Oil \& Gas Geology. 2008. 29(1): 102-106 (in Chinese)

Dolan J F, Christofferson S A and Shaw J H. Recognition of paleoearthquakes on the Puente Hills blind thrust fault, California. Science. 2003. 300(5616): 115-118

Fuis G S, Ryberg T, Godfrey N J, et al. Crustal structure and tectonics from the Los Angeles basin to the Mojave Desert, Southern California. Geology. 2001. 29(1): 15-18

He G Q, Lu S N and Li M S. Tectonic significance of large fault systems to the study of paleo-plates. Geological Journal of Universities. 1995. 1(1): 1-10 (in Chinese)

King P R. New Zealand's changing configuration in the last 100 million years: plate tectonics, basin development, and depositional setting. New Zealand Petroleum Conference Proceedings. 2000. 15

Liu W H, Lin C S, Guo Z Q, et al. Styles of inversion structures and their mechanisms of the Cenozoic Xihu Sag, East China Sea Shelf Basin. Chinese Journal of Geology. 2009. 44(1): 74-87 (in Chinese)

Luo J H, Zhou X Y, Qiu B, et al. Controls of the Talas-Ferghana Fault on the Kashi Sag, Northwestern Tarim Basin. Xinjiang Petroleum Geology. 2004. 25(6): 584-587 (in Chinese)

Moseley B A and Tsimmer V A. Evolution and hydrocarbon habitat of the South Turgay Basin, Kazakhstan. Petroleum Geoscience. 2000. 6(2): $125-136$ 
Oskin M, Sieh K, Rockwell T, et al. Active parasitic folds on the Elysian Park anticline: implications for seismic hazard in central Los Angeles, California. Geological Society of America Bulletin. 2000. 112(5): 693-707

Shaw J H and Shearer P M. An elusive blind-thrust fault beneath metropolitan Los Angeles. Science. 1999. 283(5407): 1516-1518

Wang P. Inverted rate calculation of inverted faults and its application in Jiyang Depression. Marine Geology Letters. 2010. 26(2): 49-54 (in Chinese)

Williams G D, Powell C M and Cooper M A. Geometry and kinematics of inversion tectonics. Geological Society Special Publication. 1989. 44: 3-15

Xia Y P, Liu W H, Xu L G, et al. Identification of strike-slip fault and its petroleum geology significance. China Petroleum Exploration. 2007. 12(1): 17-23 (in Chinese)

Xu H, Tang D Z, Zhang J F, et al. Formation mechanism of underpressured reservoir in Huatugou Oilfield of Qaidam Basin. Journal of Earth Science. 2011a. 22(5): 632-639
Xu H, Tang D Z, Zhang J F, et al. Factors affecting the development of the pressure differential in Upper Paleozoic gas reservoirs in the Sulige and Yulin areas of the Ordos Basin, China. International Journal of Coal Geology. 2011b. 85: 103-111

$\mathrm{Xu} \mathrm{H}$, Zhang J F, Jia C Z, et al. Influence of tectonic uplift-erosion on formation pressure. Petroleum Science. 2010. 7(4): 477-484

Zhang Y Z, Zhang M, Ma F Q, et al. Basin-range evolution and oil-gas exploration in Altun slope area of the Western Qaidam Basin. China Petroleum Exploration. 2006. 11(6): 26-32 (in Chinese)

Zheng M L, Cao C C, Li M J, et al. Formation and evolution of petroliferous basins on the southeast side of the Altun Fault Belt. Geological Review. 2003. 49(3): 277-283 (in Chinese)

Zhou X Y, Luo J H and Mai G R. Structural Features and Petroleum Geology of the Kashi Sag and its Adjacent Area in the Western Tarim Basin. Beijing: Petroleum Industry Press. 2005. 135-157 (in Chinese) 